\title{
Creativity and Creation in Early Childhood and Preschool Education Curriculum
}

\author{
Anka Jurčević Lozančić and Daria Tot \\ University of Zagreb, Faculty of Teacher Education
}

\section{Abstract}

A contemporary early childhood education curriculum is defined as a theoretical concept that is, in educational practice, constructed and co-constructed based on mutual learning, research, and participation of all participants in the educational process. This is why it is important to arrange different conditions for various activities that enable creative thinking and expression, in which children can participate. In this sense, creativity is not interpreted as a special part of curriculum, but a component of the overall educational process, which is pervasive in all segments of the curriculum. In educational practice, awareness of the values of creative expression in children is not sufficiently developed nor appropriately utilized in curriculum development, as the possibilities of its use have not been sufficiently explored. Therefore, this paper aims to contribute to the understanding and acknowledgement of children's natural, innate creativity, which needs to be nurtured, encouraged, and developed as part of the educational process, as well as to deeply consider organizational conditions and work of kindergarten teachers.

Keywords: child; curriculum; kindergarten teacher; constructivism and coconstructivism

\section{Introduction}

In everyday and scientific communication there is still no consensus on the term "creativity". Within the framework of a well-known three-dimensional approach to giftedness, or triarchic definition of giftedness, creativity is considered to be one of the three basic sets of traits characterizing a gifted individual (Cvetković Lay \& Sekulić Majurec, 2008). Creativity is not only a characteristic of exceptional individuals, but is today seen as the universal potential and strength of every individual, essential to all 
aspects of their lives and their progress in general. In this paper, we will use creativity and creative work as related terms because by encouraging and developing creativity we also encourage the development of the act of creativity, or creative work.

Although there is still no consensus on the interpretation of child creativity, it is thought to be spontaneous and expressive, being a means unto itself. Child's discovery of the world through imagination and curiosity is its authentic creative power. By observing children in many activities, we can see that children are aware of their thought processes, which should be looked at from different perspectives, and one's personal understanding of the above should be expressed in one's own personal way. In the development of creativity, special attention should be paid to early childhood. The above mentioned life period has an irreplaceable developmental function for a child's personality and its preparation for taking on an active role in the ever-changing world. Therefore, it is necessary to provide activities for children that will encourage the development of originality, flexibility, and fluency in finding solutions. And with the contemporary curriculum, the role of a child in the educational process is crucially changing (Hedges et al., 2011). The child becomes a subject in the learning process, as well as a creator of their own knowledge, provided that they are living in a stimulating environment and learning with other children and kindergarten teachers who know how to observe, listen, and actually see a child, and based on that act in accordance with the child's needs and interests (Bronfenbrenner, 1993; Petrović Sočo, 2012). Preconditions necessary for the realization of the concept which is in kindergarten's educational practice built collaboratively, i.e. which is constructed and co-constructed based on mutual learning, research, and participation of all participants in the educational process, include various transformations. They are focused on different spheres: from the mindset of kindergarten teachers and other professional kindergarten workers, to the transformation of their joint work which strives to find the most effective support for the high quality of their lives, education, and learning (Slunjski, 2011). For these reasons, a child must have a free choice of activities, use all their senses and have a quality communication and variety of interactions. For this, a pedagogical design of space is necessary, in line with children's ever-expanding interest, knowledge, and understanding.

\section{Contemporary Concept of the Early Education Curriculum}

A starting point for the contemporary approach to early education curriculum lies in the interpretation of curriculum as a theoretical concept that is built based on the practice of a particular educational institution, whose fundamental characteristics are unpredictability, multidimensionality, and complexity (Betram \& Paskal, 2002; Petrović Sočo, 2012; Slunjski, 2011; Wood \& Attfield, 2006). Although the concept of the socalled "developmentally appropriate practice" emphasizes the importance of free play, child's activities and research, and the importance of a guiding and supporting role 
of a professional kindergarten teacher, for the most part it reflects the orientation of the curriculum towards a child, emphasizing the universal (Piaget's) degrees of child development. As an alternative to such idealized universal developmental assumptions and implicit "developmentally appropriate practices", the concept of "contextually appropriate practice" came to existence (Kessle \& Swadener, 1992; Woodhead 1998; Rinaldi 2006), emphasizing that the curriculum and practice regarding early childhood must take into account different contexts, as well as family and cultural resources of the child's community. Such contemporarily conceptualized early education curriculum points to the three components of the environment in which children grow up: physical and social environment, culturally shaped and regulated customs and practices of child education, and beliefs or implicit pedagogy of parents, kindergarten teachers, and other significant adults.

The theory of ecological systems (Bronfenbrenner, 1979,2005) has had a significant impact on the reconceptualization of early childhood in context. The often cited Bronfenbrenner bioecological model emphasizes the importance of the context in which a child develops and learns, as well as the complexity of interactions with various social systems. Child's development is observed within different social systems that interact with each other. The microsystem is closest to a child and is comprised of a daily environment and relationships which the child establishes in their surroundings. The mesosystem encompasses interaction between the parts of the microsystem (for example, between parents and kindergarten teachers), and exosystems present potent influences which can indirectly affect the child. Furthermore, it should also be emphasized that the systems are not static and that macrosystem and chronosystem are mediators between dominants beliefs and values that children are surrounded with. This theory emphasizes the importance of the overall context in which child development takes place, without neglecting the individual characteristics of a child. Child development is the result of the interaction between their personal characteristics and the environment in which they are growing up. Since it largely encompasses key theses of the contemporary theories of child and childhood, Brofenbrenner's theory has been cited as the referent theoretical and methodological starting point for the development and promotion of contemporarily conceptualized early childhood and preschool education curriculum.

\section{Creativity and Creative Work as Components of Early Childhood Education}

Understanding development as a socio-cultural process is creating important implications for politics, curriculum, and educational process (Macnaughton, 2003). Instead of looking at early childhood as a universal, decontextualized developmental process, attention is focused on including children in a variety of environments, relationships, activities, and skills. An exceptional influence on the revision of the understanding of child and childhood have theoretical notions of John Dewey, Maria 
Montessori, Erik Erikson, Jean Piaget and Levi Vygotski. What they have in common is the focus on a child who, in interaction with a particular social environment, realizes their potential. Nowadays, there is almost no author who does not refer to important views of the above mentioned theoreticians, regardless of the specific professional area in which they can be applied. In this context, Early Childhood Curriculum talks about the contemporary understanding of a child as a social subject with specific needs, rights, culture, co-construction of curriculum, early and preschool curriculum education institution, and education as a learning community and pedagogical theory deriving from active reflection and research on educational practice. This is confirmed by numerous studies (for example Hedges et al., 2011; Slunjski 2011; Mackenzie et al., 2014). Slunjski (2011) defines the contemporary approach as a theoretical concept that is commonly developed in the educational practice of a kindergarten, i.e. it is constructed and co-constructed based on mutual learning, research, and participation of all participants of the educational process. This process involves searching for new ways of understanding children with the aim of finding the most effective support for the high quality of their lives, education, and learning. By keeping this in mind, it is possible to acknowledge the natural, innate creativity of a child, which should be cultivated, encouraged, and developed in the educational process through various forms of expression. The above mentioned, and many other forms of creative development, enable a higher level of expression and communication, based on the language of art (Slunjski, 2014). In this sense, creativity is not defined as a special area or a special segment of cognitive-symbolic expression, but as a component of the overall educational process, which is pervasive in all segments of the curriculum. In early childhood research (e.g. Morris et al., 2013) it is emphasized that it is extremely important that existing curricula include elements of contemporary approach by taking into account child's development of leadership in a prepared environment or structuring materials for play.

\section{Understanding Child's Creativity and Encouraging Creative Work}

The National Curriculum for Early and Preschool Education (2014) emphasizes, among other things, the significance of a child's inherent need for active research and the discovery of the immediate environment, the need for critical thinking, finding original solutions, and discovering divergent perspectives. Therefore, in early childhood and preschool age it is important to provide a child with the joy of discovery and learning that mostly relies on play and other activities interesting to the child. Wood and Attfield (2006) emphasize that children almost intuitively feel that play gives them a space of freedom, but also a range of different options, always governed by their imaginative rules, a certain inner order and sequence they want to adhere to. Play is the source of children's creativity and inventiveness (Jacobs \& Crowley, 2007). The basic value of a child's creative expression and play is in its spontaneity. The creativity 
of children is spontaneous and expressive, full of creative power and is, at the same time, a goal unto itself. A child of early and preschool age is a thinking, inventive, and creative being, open to the surrounding environment (Craft, 2000; Jurčević Lozančić, 2016). Given that a child possesses potential, openness, curiosity, and desire to explore, different possibilities of creative expression of ideas, experiences and emotions of a child can be recognized in a range of artistic areas: singing, playing, dancing, painting, drawing, acting, and so on (Mackenzie et al., 2014). There are numerous examples in the pedagogical practice that show that a child explores different thematic contents in various ways and from various perspectives. The main task of this pedagogical approach is to enable a child to master their experiences and interesting content from different fields in an integrated and dynamic process. The very way in which a child expresses themselves and creates from their earliest age, with its freshness and authenticity hones the development of their identity.

\section{Organizational Conditions and Kindergarten Teachers' Support for Child's Creativity and Creative Work}

Children are not only researchers of their environment, but they also experience this environment; to them, their environment has a subjective meaning, which is key in their attitude towards the entire educational process. Children learn what they experience, children learn in a natural, spontaneous way, so the quality of the environment in which they are growing up is important for their education and development Hedges et al., 2011).

Nowadays, it is generally accepted that the quality of early and preschool education significantly corresponds with the quality of the spatial-material environment, which attracts and encourages children to act because it simultaneously enables the affirmation of their intellectual, social, emotional, and creative potentials. The variety and constant availability of materials stimulate children to discover and solve problems they encounter, and it is this variety, as well as the diversity of environments, that is necessary to promote the full range of creative competences of children (Bruce, 2010). It is an empathetic environment that ensures a higher quality of life for all the subjects that shape it. Here, the quality relationship between an individual and their environment is reciprocal, so that both, the person and the environment, are active and mutually changing. The role of an adult is to prepare space and materials, to encourage a child to learn, but children must choose their own ways through the context of learning (Honomichl \& Chen, 2012; Weisberg, Hirsh-Pasek \& Golinkoff, 2013). Contrary to direct teaching, child play has been shown to be an important prerequisite for implicit learning of a young child (House, 2011; Pramling Samuelsson \& Johansson, 2009). By initiating the activity of play, a child creates certain meanings, which are the basis for the development of imagination and creativity. At the same time, kindergarten teachers have an extraordinary role in designing conditions that encourage and awaken child's 
immanent creative and research potential. Research has shown that the process of early childhood education greatly influences the development of individual identity (Bruce, 2010). Children need a kindergarten teacher model who will understand, support, and encourage, leave enough time for them to follow their own natural rhythm, and provide them with enough emotional warmth for a sense of security and competence (Petrović Sočo, 2012; Jurčević Lozančić, 2015). By encouraging the creative expression in children also, we are also aiming at preparing children for social change and taking on active roles in these changes. Dahlberg and Moss (2005) in their work question the technicistic starting point in defining quality as a fundamental philosophical and ethical question in terms of giving value and meaning that people bring into their interaction with children and understanding a child's role as a cocreator of knowledge. In this sense, particularly notable are starting points of Reggio Emilia pedagogy (Malaguzzi, 1998). Loris Malaguzzi emphasizes that education in which an adult is a trusted guide, friend, and an equal partner in learning, enables a child to continually learn by exploring the world, but also using their own language (in one of the so-called "hundred symbolic" languages of a child), which refers to visual, graphic, kinesthetic, verbal, gestural, and other expressive modalities. Kindergarten teachers monitor and listen to children while they are playing and make professional conclusions about their progress and interests in order to plan activities and organize the environment accordingly (Weisberg et al., 2013). In this process, they are helped by reflection and self-reflection. This conceptual and methodological approach to practice is most commonly associated with honesty and authenticity, or understandability in group communication which leads to emancipation and change of practice. One of the key changes of this pedagogical approach is recognition of the need for research and improvement of one's own educational practice with continuous personal and professional development (Antulić et al., 2016). The implementation of creativity in the Early Childhood Curriculum implies the training of kindergarten teachers for the implementation of ethnographic research, or gathering and interpretation of various ethnographic records or pedagogical documentation. It includes various forms (modalities) of communication that help in creation of research culture, reflection, involvement, and dialogue among all subjects in the educational institution. At the same time, pedagogical documentation allows insight for the kindergarten teachers into individualities of each child, and facilitates the selection of appropriate strategies to support their development and learning, which is why it represents both the means and the way of developing the curriculum. Children are encouraged to use different expressive media, enabling them to realize rich cognitive-symbolic expressions understood as an integral part of the whole educational process. With the help of these, children can creatively refine and express their ideas, ways of understanding, and experiences. A warm and stimulating support of adults and their encouragement are of paramount importance. Although communication between a child and a kindergarten 
teacher is a complex and very subtle form of the pedagogical process, the existing educational interventions by kindergarten teachers can help in the development of creativity (House, 2011). Here, it is important that the kindergarten teacher has a deeper understanding of the ways in which children use symbolic languages in their creative expression, so as to be able to deepen the possibilities of their use in shaping the early education curriculum.

\section{Conclusion}

Newer approaches to understanding children and early childhood and preschool education curriculum development recognize children as active participants in their own learning and development, together with the interdisciplinary and holistic understanding of child development and learning. The curriculum is built and developed as a process, by translating the educational concept into practice. In this process, a child's perspective is respected, together with building a common area of action and sharing experience. Here, a paradigm shift happens regarding the role and function of the educational institution and the educational process, as well as the role of a kindergarten teacher in the process of child's learning and development. This paper brings an overview of important studies and cognitions in the area of understanding of child development as a socio-cultural process, and the interpretation of the curriculum as a theoretical concept which is constructed on the basis of practice of a particular educational institution, whose basic characteristics are unpredictability, multidimensionality, and complexity. In addition to questioning views of multiple authors, we were able to make certain recommendations and guidelines for the convergence of creativity and creative work in the early education curriculum. Unlike the traditional technicalrational approach, it is necessary to understand that the effectivity of the curriculum depends more on the kindergarten teacher than on the theoretical model of the program itself. The stress is, most importantly, instead of the direct leading role of a kindergarten teacher, put on much more diverse, subtle, democratic, and humane roles. In the curriculum and the educational process, the emphasis should be on child's uniqueness and unparalleledness. Focus is shifted to increasing the kindergarten teacher's influence and involvement in their personal professional learning and qualifiedness for independent research and changing of their educational practice. Along with the above mentioned changes, the focus should also be on the importance of the changes related to recognition of early childhood and preschool education system as an equally valuable and equal part of the whole educational system. This gives a greater value to the contemporary understanding of child development and learning, especially in the context of the stimulating environment and creativity development. By stressing the importance of the role of a kindergarten teacher, we can conclude there is a need for a deeper understanding of creativity and creative work, and their implications for the professional development of kindergarten teachers. 


\section{References}

Antulić, S., Opić, S., \& Tot, D. (2016). Evaluation Level in the Process of Self-Evaluation of Educational Institution. Croatian Journal of Education, 18 (Sp.Ed.1), 31-46. https://doi. org/10.15516/cje.v18i0.2183

Bertram, T., \& Pascal, C. (2002). What counts in early learning? In O. N. Saracho \& B. Spodek (Eds.), Contemporary Perspectives on Early Childhood Curriculum (pp. 241-259). Information Age Publishing.

Bronfenbrenner, U. (1979). The Ecology of Human Development: Experiments by Nature and Design, Harvard University Press.

Bronfenbrenner, U. (1993). Ecological Models of Human Development. In M. Gauvain \& M. Cole (Eds.), Readings on the development of children (pp. 37-43). Freeman.

Bronfenbrenner, U. (2005). Making Human Beings Human: Bioecological Perspectives on Human Development. Sage Publications Inc.

Bruce, T. (2010). Play, the universe and everything! In J. Moyles (Ed.), The Excellence of Play (pp. 277-290). Open University Press.

Craft, A. (2000). Creativity Across the Primary Curriculum: Framing and Developing Practice. Routledge.

Cvetković Lay, J., \& Sekulić Majurec, A. (2008). Darovito je, što ću s njim? Alinea.

Dahlberg, G., \& Moss, P. (2005). Ethics and Politics in Early Childhood Education. Abingdon: Routledge Falmer. https://doi.org/10.4324/9780203463529

Hedges, H., Cullen, J., \& Jordan, B. (2011). Early years curriculum: funds of knowledge as a conceptual framework for children's interests. Journal of Curriculum Studies, 43(2), 185205. https://doi.org/10.1080/00220272.2010.511275

Honomichl, R. D., \& Chen, Z. (2012). The role of guidance in children's discovery learning. Wiley Interdisciplinary Reviews. Cognitive Science, 3(6), 615-622. https://doi.org/10.1002/ wcs.1199

House, R. (2011). Too Much, Too Soon? Early Learning and the Erosion of Childhood. Hawthorn Press.

Jacobs, G., \& Crowley, K. (2007). Play, projects, and preschool standards: Nurturing children's sense of wonder and joy in learning. Corwin Press.

Jurčević Lozančić, A. (2015). The Road to Quality in the Theory and Practice of Early Learning: Identity of the Preschool Teacher Profession. Croatian Journal of Education, 17(1), 125-135. https://doi.org/10.15516/cje.v17i0.1553

Jurčević Lozančić, A. (2016). Socijalne kompetencije u ranom djetinjstvu. Učiteljski fakultet Sveučilišta u Zagrebu.

Kessler, S., \& Swadener, B. (1992). Reconceptualizing the Early Childhood Curriculum. In S. A. Kessler \& B. Swadener, B. (Eds.), Reconceptualizing the Early Childhood Curriculum Beginning the Dialogue (pp. 43-61). Teachers College, Columbia University.

Mackenzie, C. A., Edwards, S., \& Moore, D. (2014). Young Children's Play and Environmental Education in Early Childhood Education. London: Springer. https://doi.org/10.1007/978$\underline{\text { 3-319-03740-0 }}$

Macnaughton, G. (2003). Shaping Early Childhood: Learners, Curriculum And Contexts. Open University Press. 
Malaguzzi, L. (1998). History, Ideas, and Basic Philosophy- An Interview with Lella Gandini. In C. P. Edwards, L. Gandini, \& G. Forman (Eds.), The Hundred Languages of Children - The Reggio Emilia Approach, Advanced Reflections (pp. 49-97). Ablex Publishing Corporation.

Morris, B. J., Croker, S., Zimmerman, C., Gill, D., \& Romig, C. (2013). Gaming science: The "gamification" of scientific thinking. Frontiers in Psychology, 4, Article 607. https://doi. org/10.3389/fpsyg.2013.00607

Nacionalni okvirni kurikulum za predškolski odgoj i obrazovanje te opće obvezno i srednjoškolsko obrazovanje (2014). http://public.mzos.hr/Default.aspx?sec=2685

Petrović-Sočo, B. (2012.) Rekonceptualizacija Hrvatskog kurikuluma ranoga odgoja i obrazovanja. In I. Pehlić, E. Vejo, \& A. Hasanagić (Eds.). Suvremeni tokovi u ranom odgoju (pp. 57-74). Islamski pedagoški fakultet Univerziteta u Zenici.

Pramling Samuelsson I., \& Johansson, E. (2009). Why do children involve teachers in their play and learning? European Early Childhood Education Research Journal, 17(1), 77-94. https://doi.org/10.1080/13502930802689053

Rinaldi, C. (2006). In Dialogue with Reggio Emilia. Routledge, Taylor \& Francis Group.

Slunjski, E. (2011). Različiti pristupi istraživanju i tvorbi kulrikuluma. In D. Maleš (Ed.), Nove paradigme ranog odgoja (pp. 179-208). Filozofski fakultet Sveučilišta u Zagrebu, Zavod za pedagogiju.

Slunjski, E. (2014). Kako djetetu pomoći da ... (p)ostane kreativno i da se izražava jezikom umjetnosti. Element.

Weisberg, D. S., Hirsh-Pasek, K., \& Golinkoff, R. M. (2013). Guided play: Where curricular goals meet a playful pedagogy. Mind, Brain, and Education, 7(2), 104-112. https://doi. org/10.1111/mbe.12015

Woodhead, M. (1998). Quality In Early Childhood Programmes: A Contextually Appropriate Approach. International Journal Of Early Years Education, 6(1), 5-17. https://doi. org/10.1080/0966976980060101

Wood, E., \& Attfield, J. (2006). Play, Learning and the Early Childhood Curriculum. Paul Chapman Publishing. https://doi.org/10.4135/9781446280393

\author{
Anka Jurčević Lozančić \\ Department of Education \\ Faculty of Teacher Education \\ University of Zagreb \\ Savska cesta 77, 10000 Zagreb, Croatia \\ anka.jlozancic@ufzg.hr
}

\title{
Daria Tot
}

Department of Education

Faculty of Teacher Education

University of Zagreb

Savska cesta 77, 10000 Zagreb, Croatia

daria.tot@ufzg.hr 


\section{Kreativnost i stvaralaštvo u kurikulu ranoga i predškolskoga odgoja i obrazovanja}

\section{Sažetak}

Suvremeno koncipiran kurikul ranog odgoja i obrazovanja odreduje se kao teorijska koncepcija koja se u odgojno obrazovnoj praksi konstruira i sukonstruira na temelju zajedničkog učenja, istraživanja i participacije svih sudionika odgojnog procesa. Zato je važno organizirati različite uvjete u kojima djeca imaju brojne prilike sudjelovati u aktivnostima koje omogućuju kreativno i stvaralačko promišljanje i izražavanje. U tom smislu kreativnost se ne tumači kao posebno područje kurikula, već kao sastavnica cjelokupnog odgojno-obrazovnog procesa koja je utkana u sve segmente kurikula. U odgojno-obrazovnoj praksi svijest o vrijednostima kreativnih ekspresija djece u oblikovanju kurikula nije dovoljno razvijena niti su mogućnosti njihovog korištenja dovoljno istražene. Stoga se ovim radom nastoji doprinijeti razumijevanju i uvažavanju kreativnosti kao djetetova potencijala, koji tijekom odgojno-obrazovnog procesa treba njegovati, poticati i razvijati te dublje sagledati organizacijske uvjete $i$ načine djelovanja odgojitelja u dječjem vrtiću.

Ključne riječi: dijete; kreativnost, kurikul; odgojitelj, sukonstruktivizam 